\title{
Optimizing the Artificial Lighting in a Smart and Green Glass Building-integrated Semi-Transparent Photovoltaics: A Multifaceted Case Study in Egypt
}

\author{
Mohamed O. Ahmed, Ahmed K. Madkor, Peter Makeen, Shehab Edin I. Betelmal, \\ Minatallah M. Hassan, Mohamed M. Abdelsamee, Ahmed Ayman, Mohamad H. El-Adly, \\ ASHRAF NESSIM AND SAMEH O. ABDULlATIF* \\ FabLab in the Center for Emerging Learning Technologies (CELT) \\ Faculty of Engineering \\ The British University in Egypt (BUE) \\ El-Sherouk 11837, Cairo, EGYPT
}

\begin{abstract}
Numerous increases in $\mathrm{CO}_{2}$ emissions are recognizable nowadays. Consequently, building integrated photovoltaics (BIPV) glows up as a trendy future solution. BIPVs are introduced by substituting one of the building components with a green energy harvesting source seeking for sustainability. Herein, we propose a BIPV techno-economic feasibility by utilizing in-Lab fabricated semi-transparent solar cells as a glass interface. Three alternatives have been taken into consideration with proposing on-roof Photovoltaic (PV) system (alternative \#1) and semi-transparent solar cells working as glass interfaces (alternative \#2) while keeping the governmental grid as a reference alternative (alternative \#3). Daylight simulations and electric lighting loads optimization are investigated showing an overall energy budget per alternative. An optimum alternative with an overall excess energy of around $88 \mathrm{MWh}$ as annual energy production was reached, while satisfying $100 \%$ of the targeted electrical loads. Levelized cost of energy (LCOE) is demonstrated as an economic parameter to evaluate the three proposed alternatives.
\end{abstract}

Key-Words: - Energy management, Load management, Lighting, Optoelectronic devices, Photovoltaic cells, Solar energy.

Received: September 12, 2020. Revised: January 2, 2021. Accepted: January 31, 2021. Published: February 8, 2021.

\section{Introduction}

The need for alternative energy sources is a global urgent issue, where energy consumption, based on fossil fuels, is increasing worldwide, leading for more $\mathrm{CO}_{2}$ emissions [1]. Egypt's electricity generation depends mainly on natural gas and oil [2, $3]$. In 2018 , Egypt produced $0.71 \%$ of the world's $\mathrm{CO}_{2}$ emissions, making it the $23^{\text {rd }}$ source of carbon emissions worldwide. Consequently, research community in Egypt focused on allocating the energy consumption distribution among various sectors, seeking for green alternatives. In [4], it was estimated that over 55\% of Egypt's energy consumption can be attributed to buildings (Commercial, industrial, and residential). Furthermore, lighting load constitutes an estimated $28-30 \%$ of the total Egyptian power consumptions $[5,6]$. Thus, studies have risen to inspect alternative energy sources, in the Egyptian context, to meet the increasing energy consumption, and green energy needs, through techno-economic feasibilities [6-10]. Building-integrated Photovoltaics (BIPV) has been introduced in literature as a booming solution towards green, smart and sustainable buildings [1114]. BIPVs are technologies that replace conventional building components with components that harness solar energy [15]. One of these components can be glass windows, to be replaced by semi-transparent solar cells to provide a new range of possibilities in terms of smart building sustainability. Semi-transparent solar cells have been studied as a possible green energy source in various contexts $[16,17]$. The variables that seem critical to the studies in the technical aspect were window to wall coverage ratios (WWR), orientation of building walls, transparency, and surface area/volume ratio of rooms [18]. While this work targets artificial lighting loads as its main optimization goal, other studies have targeted 
heating [19-21], ventilation [22], and air conditioning loads $[23,24]$ in BIPVs.

The semi-transparent PV technology has the potential to significantly reduce $\mathrm{CO}_{2}$ emissions and fossil fuel consumptions by using alternative sources of green energy such as solar energy [17]. A window replacement option in terms of energy saving in multiple conditions and factors has been investigated in [25], through studying the WWR and window orientations impacts. Additionally, a new figure of merit was introduced in [26], called the NEB (Net Energy/Electrical Benefit), with considering heat loss and artificial lighting as a key evaluating parameters. Using NEB, various semitransparent PVs were tested where a 70\% WWR semi-transparent PV solutions showed the most energy saving option [25]. Another study by Peng et. al in [18] used a c-Si based laminate semitransparent PVs in constructing a window where electrical power, thermal energy, and daylighting performance were investigated. The window was $1.4 \times 1.7 \mathrm{~m}^{2}$ and produced $1940 \mathrm{Wh} /$ day. The proposed window in [18] was then integrated in a BIPV with artificial lighting loads of $431 \mathrm{Wh} /$ day per room making the net energy production 1509 $\mathrm{Wh} /$ day $[18,27]$.

Another critical parameter in fabricating semitransparent PVs is the PV transparency as it enables a trade-off between PV efficiency and daylight utilization [28, 29]. Dingming et. al in [17] performed an in-depth analysis of the daylight aspect of semi-transparent PV windows. The study highlighted Cadmium telluride (CdTe) PV window daylight performance in terms of quality of light and color. It was shown that the windows provided acceptable lighting at a $60 \%$ WWR; however, the authors didn't provide any analysis concerning the extracted electrical power [17].

In this study, three techno-economic feasibilities are proposed with enabling on-roof PV system (alternative \#1) as well as semi-transparent solar cells (alternative \#2), while considering the conventional grid supply scenario as a reference alternative (alternative \#3). The study demonstrates the utilization of both sunlight and indoor lighting through bifacial solar cell harvesters. Three fabricated prototypes are tested, with demonstrating a complete integration process to provide larger area semi-transparent solar cells. Daylighting is simulated at various windows transparency levels, seeking for an optimum artificial lighting load for a seven floor office building in Egypt. Technical as well as economic parameters for each alternative are simulated and the overall systems performances are evaluated.

\section{System Under feasibility Study}

The proposed BIPV, under investigation, is chosen to be localized in New Cairo, Egypt (long $31^{\circ} 29^{\prime} 35.47 " \mathrm{E}$, latitude $30^{\circ} 1^{\prime} 33.91 " \mathrm{~N}$ ) as shown in Fig.1-a. The building footprint is about $1150 \mathrm{~m}^{2}$ with $64 \mathrm{~m}$ length along the north axis; its area is $3928 \mathrm{~m}^{2}$ with 10 meters Setbacks from all sides. The building consists of a ground floor, 6 typical floors and roof, each floor has 3.25 meters height. Consequently, the total building height is around 23 meters. All data related to the chosen BIPV are listed in Table 1. Another adjacent building (26 m height) locates beside the office building and casts a shadow over the project from the eastern direction as shown in Fig. 1-b. An overview of the building with its southeast and southwest views is presented in Fig. 1-c and Fig. 1-d. BIPV under feasibility consists of a photovoltaic on-roof array (alternative \#1) and/or semi-transparent photovoltaic (PV) system (alternative \#2) connected to a maximum power point tracking system (MPPT), utility grid, DC-AC inverter and net metering. In this study, three alternatives are investigated; a normal concrete building with lighting loads fed from the grid is studied as the reference case (alternative \#3). Another alternative utilizes normal commercial Sibased PV system on-roof (alternative \#1). The final alternative (alternative \#2) utilizes double glazing semi-transparent bifacial PVs for light harvesting and daylight utilization as well as keeping the onroof PV modules.

\subsection{Load Topology}

The electric loads in the building understudy can be represented by lighting loads, normal sockets, power sockets, air conditioners and light current systems such as fire alarm systems. The current feasibility integrates the lighting load and the fire alarm system to be supplied from BIPV renewable resources.

Luminaire LEDs type 33 watts manufactured by PHILIPS Company have been used in this study. The specification of the luminaire presented in Table 2. The consumption of lighting load has been calculated for one year based on 20 days per month and 10 hours per day. A simulation has been implemented using DIALUX program to ensure an average of 300 lux for the overall building according to the Egyptian and British codes.

The DIALUX simulation has been implemented in a room $12 \mathrm{~m} \mathrm{x} 14 \mathrm{~m}$ to be generalized for the buildings, as shown in Fig. 2. The minimum luminance has been reached is 280 lux at corners and maximum 360 lux in the center. The total luminaires that satisfied the required luminance are 


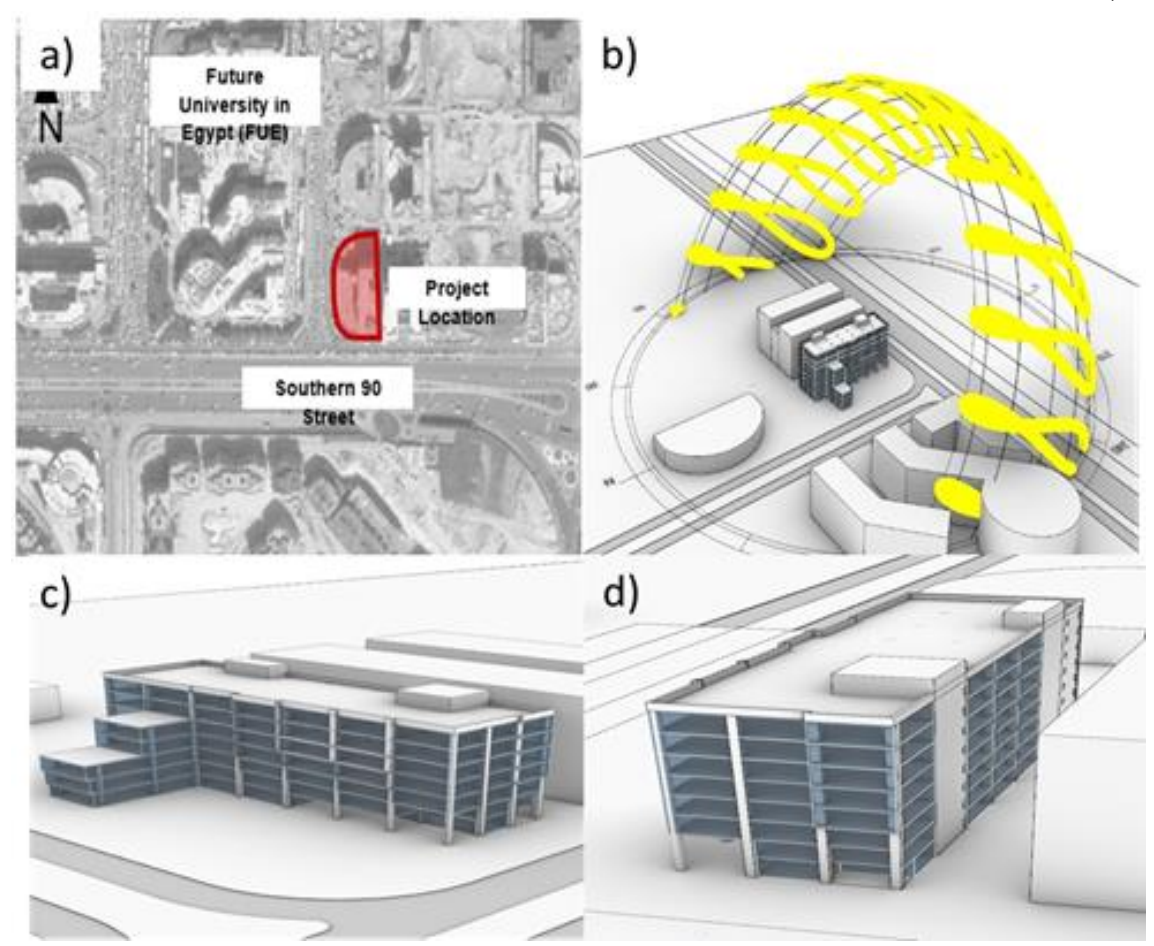

Fig. 1. a) Project location and surroundings, b) Aerial view showing surroundings and solar path over the year, c) Southwest view of the building and d) Southeast view of the building.

20 luminaires and the distances between each two LEDs were ensured according to the British and Egyptian standards.

An estimation of the total number of luminaires of the ground floor has been calculated to reach 144 LED luminaires. Consequently, the overall required lighting luminaires for the building are estimated to be 1099 luminaires (cf. Fig. 3). Therefore, the total power consumed yearly by lighting loads and fire alarm systems is $87.6 \mathrm{MWh} /$ Year as listed in Table 3. Additionally, a rough estimation for the overall energy consumption of the building, based on the Egyptian code, was estimated, excluding lighting and fire alarms, to be $5705 \mathrm{MWh} /$ Year, as listed in Table 3 under other loads. Following the reference alternative (alternative \#3), where a conventional concrete building is supplied through the grid, and the electrical tariff for $1 \mathrm{kWh}$ is 1.45 EGP. Consequently, the cost per month estimated to be 10,593 EGP/Month for 7.3 MWh/Month. This cost with the associated levelized cost of energy (LCOE) of 1.45 EGP will be considered as the reference to evaluate the other two proposed alternatives.

Table 1. Proposed BIPV under feasibility study

\begin{tabular}{|l|c|}
\hline Site Name & $\begin{array}{l}\text { Office Building in } \\
\text { Cairo. }\end{array}$ \\
\hline Roof area & $983 \mathrm{~m}^{2}$ \\
\hline Number of Floors & 7 \\
\hline South Side Area & $243 \mathrm{~m}^{2}$ \\
\hline North Side Area & $382 \mathrm{~m}^{2}$ \\
\hline East Side Area & $818 \mathrm{~m}^{2}$ \\
\hline West Side Area & $287 \mathrm{~m}^{2}$ \\
\hline
\end{tabular}



Fig. 2. Distribution of luminaires in the proposed room

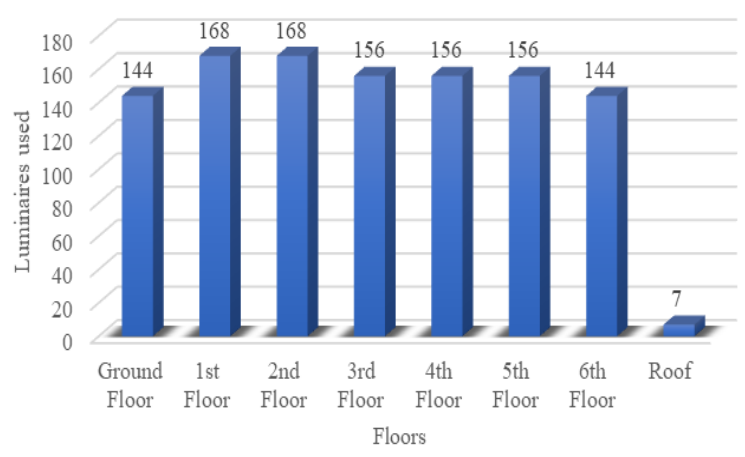

Fig. 3. Number of Luminaires on each floor

\subsection{Semi-transparent Solar Cells}

The utilization of glass building in embedding semitransparent solar cells is considered as one of the key challenges in the current study. Herein, mesostructured-based solar cells (MSSCs) have 
been used to demonstrate the semi-transparent solar cell concept. MSSCs, first introduced in our previous work [30], includes solar cells with mesoporous $\mathrm{TiO}_{2}$ layer acting either as an active layer or as an electron transport layer. The current feasibility introduces both dye sensitized solar cells (DSSCs) and Perovskites solar cells (PSCs) as semitransparent solar cells for BIPV application.

Following our previous investigation in $[28,30$ 33 ], it can be concluded that DSSCs are capable of acting as semi-transparent solar cells with tunable transparency/efficiency with respect to the mesoporous active layer thickness (cf. Fig 4-a). 5 $\mathrm{cm} \times 5 \mathrm{~cm}$ DSSCs are fabricated with $11 \mathrm{~mm}$ FTO coated glass electrodes, acting as a double glazing window. N719 standard dye is used where a complete recipe can be found in [28]. Three fabricated and characterized prototypes have been examined with various efficiencies as well as transparencies; see Fig 4-b and Table 4. Additionally, as the counter electrode of the cell is fabricated using FTO coated glass; the cell has been designed to harvest indoor lighting as well. The complete bifacial cells parameters are listed in table 4.

To feasibly assemble a system that can be integrated into a large building, the construction of a window for a single area of coverage is considered. The window fabrication process could undergo two possible routes, the enlargement of the individual cell, and the construction of windows through using current produced samples. The approach of choice was the latter option. The proposed design integrates the fabricated cell as a unit in an array of connected cells (cf. Fig. 5). The proposed window is connected using transparent adhesive to decrease loss of transmittance.

Table 2. Specification of Luminaire LED

\begin{tabular}{|l|l|}
\hline Luminaires LED type & $\begin{array}{l}\text { PHILIPS RC133V } \\
\text { W62L62 } \\
\text { LED36S/840 OC }\end{array}$ \\
\hline Luminous flux (Luminaire) & $3600 \mathrm{~lm}$ \\
\hline Luminaire Wattage & $33.0 \mathrm{~W}$ \\
\hline $\begin{array}{l}\text { Luminaire classification } \\
\text { according to CIE }\end{array}$ & 100 \\
\hline Fitting & $\begin{array}{l}\text { LED36S/840/- } \\
\text { (Correction Factor } \\
1.000)\end{array}$ \\
\hline
\end{tabular}

Table 3. Loads calculation

\begin{tabular}{|l|l|l|l|l|}
\hline & W & \# of units & W/h & MWh /y \\
\hline LED & 33 & 1099 & 36267 & 87.0408 \\
\hline Fire Alarm & 110 & 1 & 110 & 0.6336 \\
\hline
\end{tabular} $\begin{aligned} & \text { Total lighting loads and fire alarm } \\
& \text { loads per year }\end{aligned}$

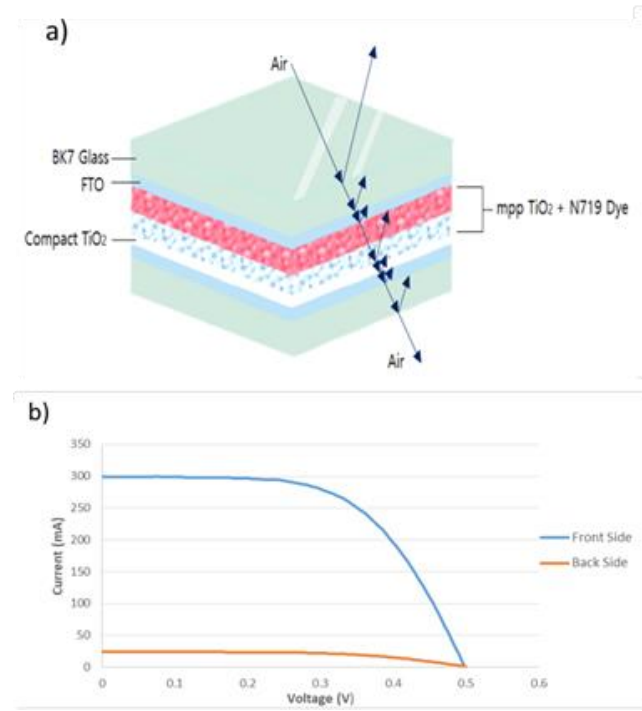

Fig. 4. (a) a schematic for MSSC used as a semi-transparent solar cell. (b) I-V curve for front and back contact harvesting using $43 \%$ transparent solar cell.

Table 4. Semi-transparent MSSCs parameters

\begin{tabular}{|l|c|c|c|}
\hline Cell \# & MSSC-1 & MSSC-2 & MSSC-3 \\
\hline T (\%) & $33 \%$ & $43 \%$ & $53 \%$ \\
\hline $\begin{array}{l}\text { Direct light } \\
\text { eff. (\%) }\end{array}$ & $3.12 \%$ & $2.52 \%$ & $1.78 \%$ \\
\hline $\begin{array}{l}\text { Diffused } \\
\text { light eff. } \\
(\%)\end{array}$ & $0.98 \%$ & $0.51 \%$ & $0.43 \%$ \\
\hline $\begin{array}{l}\text { Indoor light } \\
\text { eff. (\%) }\end{array}$ & $0.21 \%$ & $0.19 \%$ & $0.08 \%$ \\
\hline Glazing & \multicolumn{3}{|c|}{ Double } \\
\hline $\begin{array}{l}\text { Thickness } \\
(\mathrm{mm})\end{array}$ & 22.54 & 22.32 & 22.15 \\
\hline
\end{tabular}


a)
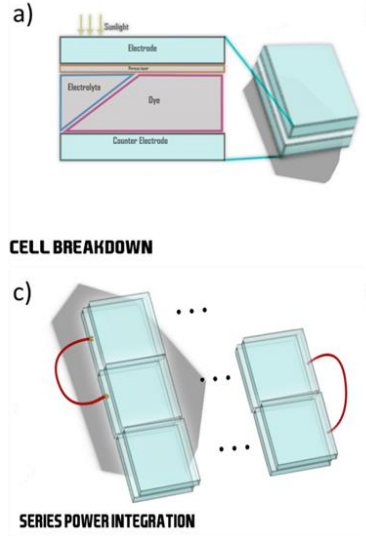

b)

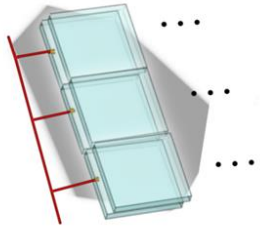

PARALLEL POWER INTEGRATION

d)

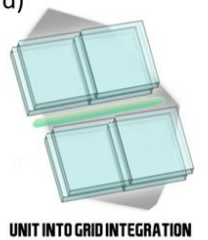

Fig. 5. Cell to window integration procedure

\section{Technical Results}

Looking forward to providing several ways to generate energy for building and saving cost, two alternatives for the solar system integration in the proposed BIPV were investigated. One of the alternatives is using the ordinary Si-based PV system to cover the roof of office building (alternative \#1), with estimated space up to $983 \mathrm{~m}^{2}$. In the other alternative, semi-transparent solar cells have been utilized with enabling the day-lighting privileges on one hand and harvesting both sunlight as well as artificial lighting through the proposed bifacial solar cells from the other hand (alternative \#2). While alternative three is kept as a reference case where the lighting and fire alarms loads are supplied from the grid as indicated earlier.

\subsection{Alternative \#1: $\mathrm{Si}=$ based PVs On-roof}

As mentioned earlier in the introduction, the target of this study is to minimize the consumption cost of the artificial lighting loads in the proposed BIPV. Consequently, the current alternative introduces the utilization of the roof area to implement a number of solar panels to supply the targeted load seeking for low cost and low $\mathrm{CO}_{2}$ emissions. A complete sizing process has been implemented using an online PV sizing tool developed by our group and can be accessed through [34]. In this case, the building is assumed to be with concrete solid faces with no sunlight entering the building. By utilizing the roof area of $983 \mathrm{~m}^{2}, 174$ units of PV panels, each with $335 \mathrm{~W}$ have been sized. As indicated in the exported report presented in Fig. 6, the data of each month have been observed to determine the annual produced energy by $99.1 \mathrm{MWh} /$ Year. Moreover, Table 5 shows the data information and results from implemented PV panels on the roof, including the power inverter and the specific power required from each cell to covering the total consumption. It can be observed from this alternative that $100 \%$ of the targeted load will be supplied by the on-roof PV system. Additionally, excess annual energy production of $11.5 \mathrm{MWh} /$ Year will be supplied to the grid through the net metering system. This provides around $0.2 \%$ of the overall system consumptions excluding the target loads.

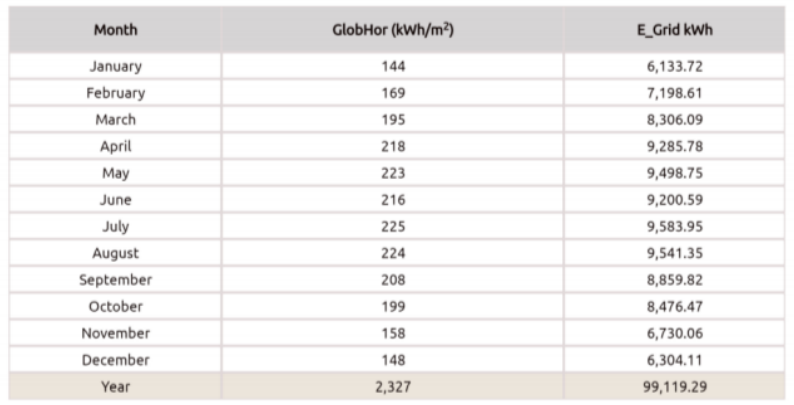

FIG. 6. A detailed sizing report from PV CELT

Table 5. Alternative \#1: PV on-roof Technical Analysis

\begin{tabular}{|l|l|}
\hline Average Monthly Consumption & $\begin{array}{l}7.306 \\
\mathrm{MWh}\end{array}$ \\
\hline $\begin{array}{l}\text { Power required for covering the } \\
\text { consumption }\end{array}$ & $\begin{array}{l}58.25 \\
\mathrm{kWp}\end{array}$ \\
\hline $\begin{array}{l}\text { Number of Modules (Using Jinko - } \\
335 \mathrm{~W})\end{array}$ & $\begin{array}{l}\text { Units } \\
\text { Power of Inverter }\end{array}$ \\
\hline $\begin{array}{l}48.54 \\
\mathrm{~kW}-\mathrm{AC}\end{array}$ \\
\hline Annual Produced Energy & $\begin{array}{l}99.119 \\
\mathrm{MWh}\end{array}$ \\
\hline The tilt angle of the PV Panels & $\begin{array}{l}28 \\
\text { Degree }\end{array}$ \\
\hline Circuit breaker Capacity & $125 \mathrm{~A}$ \\
\hline $\begin{array}{l}\text { Covering the Percentage of total } \\
\text { power }\end{array}$ & $100 \%$ \\
\hline
\end{tabular}

3.2 Alternative \#2: Glass Building with Semitransparent Solar Cells

In this alternative glass BIPV is proposed with integrating semi-transparent solar cells as a decorative glass interface for the BIPV four faces. The suggested design enables the utilization of daylighting in optimizing the artificial lighting loads used in the current feasibility. Moreover, the integrated semi-transparent cells harvest the sunlight, direct and diffused, as well as artificial indoor lighting in a bifacial manner. According to the Illuminating Engineering Society (IES), two methods are approved for the daylighting calculations: Spatial Daylight Autonomy (sDA) and Annual Sunlight Exposure (ASE) [35]. In the coming paragraphs, both methods will be illustrated.

Spatial Daylight Autonomy is a measure of daylight luminance sufficiency for a given area, reporting a percentage of floor area that exceeds a specified luminance (e.g., 300 lux) for a specified percentage of the analysis period [35]. Accordingly, it examines whether a space receives enough daylight during standard operating hours (8 a.m. to 6 p.m.) on 
an annual basis using hourly luminance grids on the horizontal work plane.

The sDA of the building has been proposed in Fig. 7. Acceptance Criteria in the case of LEED v4, sDA300/50\% indicates that a certain present of area must meet or exceed 300 lux for at least $50 \%$ of the working hours per year. The proposed simulation has been conducted for $43 \%$ transparency double glazing glass, as described in section 2.2 (MSSC-2).

On the other hand, Annual Sun Exposure (ASE) measures the percentage of floor area that receives more than 1000 lux of direct sunlight for more than 250 occupied hours per year (c.f. Fig8). As such, this study begins by calculating only the direct sun falling on a horizontal outdoor surface. This is then multiplied by window transmittance and used to select sun positions that only have values above the 100 lux threshold. The resulting sun vectors are then used in a "sunlight hours" calculation to determine the floor area that exceeds 250 hours per year. The result of the ASE Analysis showed that the ASE is almost equal in all floors. 33\% of each floor area receives more than 1000 lux of direct sun for more than 250 occupied hours per year as illustrated in in Fig. 8.

According to [36] daylight glare evaluation has been the recent focus of research on visual comfort since newer office buildings have large glass facades offering daylight provision and outdoor views. Available glare indices are related to source luminance size and location, view direction and background luminance.

Following the daylighting analysis implemented above, simulations have been used to reduce the total power by a specific percentage based on the sunlight over the office building. Therefore, the percentage of reducing the total power for each floor has been calculated according to the intensity of the sun on each side of the building. The daylight coverage percentage for each floor is illustrated in Fig. 7. Consequently, the needed artificial lighting loads have been recalculated to be $55.69 \mathrm{MWh} /$ Year with average reduction reaches $36 \%$ with respect to the model proposed in alternative \#1 (see fig. 9). In the current alternative, MSSC- 2 with $43 \%$ transparency is utilized in implementing the BIPV understudy. Semi-transparent solar cell is crucial technology for providing huge support to cover the energy consumption from loads. By optical modeling and simulations, the total power observation from transparent windows solar cells has been estimated by $44.5 \mathrm{MWh} /$ Year, following the data provided in section 2.2. The calculations have been estimated assuming the south side is directed to direct.

Finally, in the current alternative, MSSC- 2 with $43 \%$ transparency is utilized in implementing the BIPV understudy. Semi-transparent solar cell is crucial technology for providing huge support to cover the energy consumption from loads. By optical modeling and simulations, the total power observation from transparent windows solar cells has been estimated by $44.5 \mathrm{MWh} / \mathrm{Year}$, following the data provided in section 2-2. The calculations have been estimated assuming the south side is directed to direct sunlight, while the north side is directed to diffused sunlight. Both east and west sides are treated as $50 \%$ of the time directed to direct sunlight and another 50\% to diffused sunlight. On the other hand, indoor harvesting is simulated assuming 200 lux artificial lighting with considering the associated spectral mismatching. The overall energy budget of alternative \#2 is listed in Table 6. It can be observed from this alternative that still $100 \%$ of the lighting and fire alarm load is satisfied. However, more excess energy, $87.91 \mathrm{MWh} / Y$ ear, is now supplied to the grid per year. Herein, $1.54 \%$ of the overall energy turns to be green. This is approximately eight times the excess energy demonstrated in alternative \#1.

Table 6. Alternative \#3 Energy Budget

\begin{tabular}{|l|c|}
\hline Consumed or supplied energy & $\begin{array}{l}\text { Energy in } \\
\text { MWh/Year }\end{array}$ \\
\hline $\begin{array}{l}\text { Lighting loads and fire alarms } \\
\text { with including daylight effect }\end{array}$ & 55.69 \\
\hline $\begin{array}{l}\text { On-roof PV system annual } \\
\text { production }\end{array}$ & 99.1 \\
\hline $\begin{array}{l}\text { Semi-transparent (43\%) glass } \\
\text { sides annual production }\end{array}$ & 44.5 \\
\hline Excess energy directed to the grid & 87.91 \\
\hline
\end{tabular}

\section{Economic Analysis}

The second portion of this study investigates the economic analysis for the proposed three alternatives. In alternative \#3, as the governmental grid is used as the main source of energy, the LCOE can be taken directly as the electricity tariff (1.45 $\mathrm{EGP} / \mathrm{kWh}$ for 2020). Assuming a project lifetime of 20 years, with inflation rate of $10.4 \%$, an average LCOE for alternative \#3 can be calculated to be 5.2 EGP/kWh. In alternative \#1, all the economic analysis have been implemented using the PV-ON online tool [34], showing an average LCOE of 0.92 $\mathrm{EGP} / \mathrm{kWh}$ across the same lifetime of the project. 


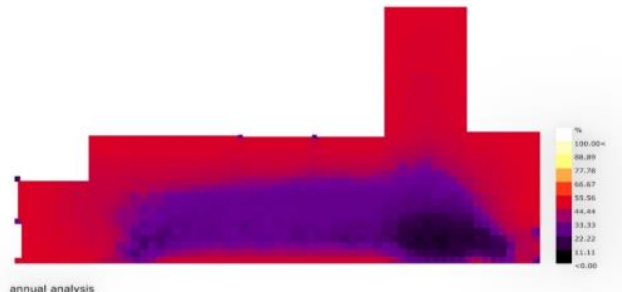

(a) Diagram shows sDA study on the $\mathrm{G}$ floor which has area $=32 \%$ covered with Daylight

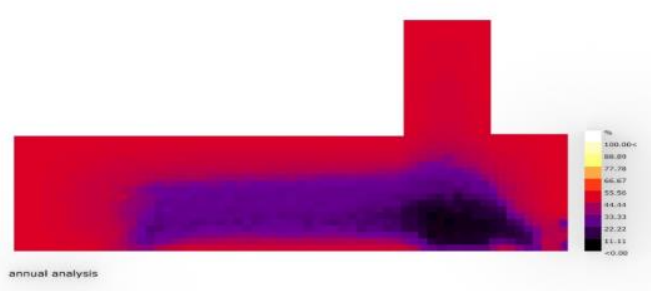

(c) Diagram shows sDA study on the 2nd floor which has area $=36.6 \%$ covered with Daylight

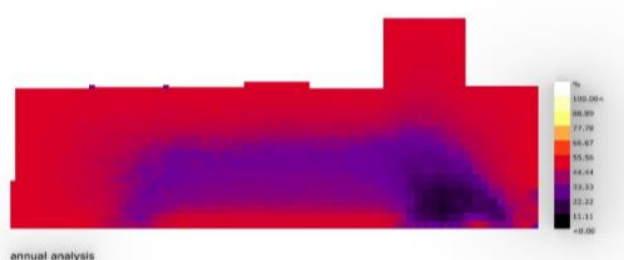

(e) Diagram shows sDA study on the 4th floor which has area $=36 \%$ covered with Daylight

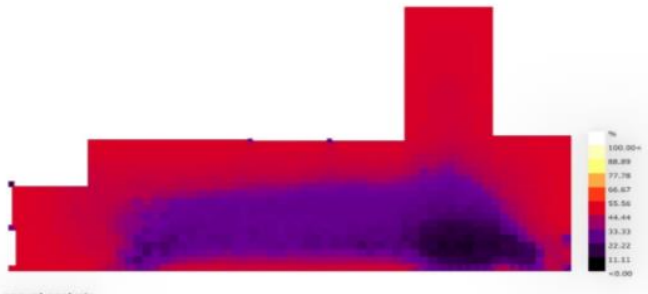

(b) Diagram shows sDA study on the 1st floor which has area $=35 \%$ covered with Daylight

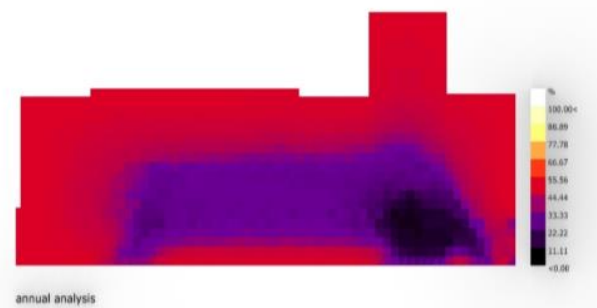

(d) Diagram shows sDA study on the 3rd floor which has area $=35 \%$ covered with Daylight

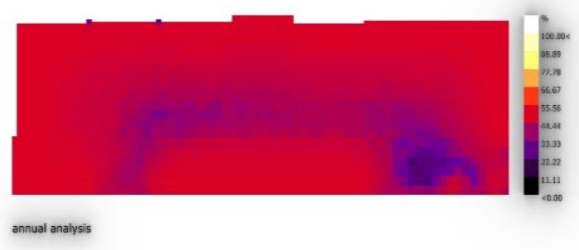

(f) Diagram shows sDA study on the 5th floor which has area $=40.2 \%$ covered with Daylight

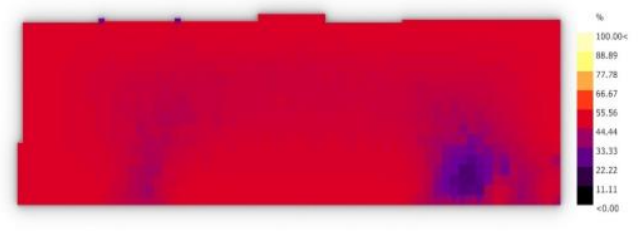

annual analysis

(g) Diagram shows sDA study on the 6 th floor which has area $=41.5 \%$ covered with Daylight

Fig. 7. sDA analysis of each floor in the proposed building.

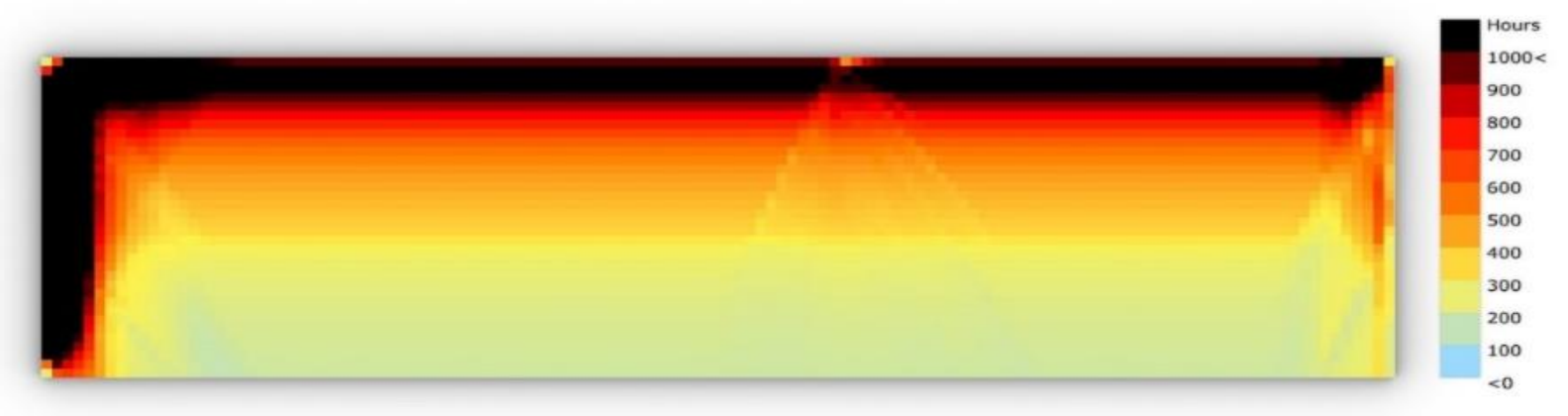

SunlightHours Analysis

Fig. 8. ASE study on the 5th floor which has area $=33 \%$ receives more than 1000 lux of DIRECT SUN ONLY for more than 250 occupied hours per year.

In order to investigate alternative \#2 from economic prospective, a full estimation for the cost of the MSSC semi-transparent solar cell is needed. The cost is analyzed as direct and indirect cost. Direct cost includes materials involved in the manufacturing process (see Table 7), while indirect costs includes labour cost and machines depreciation. In the current study, two types of FTO coated glass have been used; the first is commercial glass from Sigma Aldrich, while the second is in-lab fabricated using CVD techniques [37]. Logically, the in-lab fabricated FTO glass showed lower direct 
cost than the corresponding commercial one (52.42 EGP to 96.52 EGP per $5 \times 5 \mathrm{~cm}^{2}$ cell). As an overall fabrication cost the MSSC- 2 cost using in-Lab FTO coated glass records $64.59 \mathrm{EGP} / \mathrm{cell}$. Consequently, the overall LCOE for alternative \#3 reached 9.85 $\mathrm{EGP} / \mathrm{kWh}$.

Table 7. MSSC COST PER LAYER

\begin{tabular}{|l|l|l|}
\hline Material & Quantity & $\begin{array}{l}\text { Cost in } \\
\text { euro }\end{array}$ \\
\hline $\mathrm{TiO}_{2}$ powder & $3.5 \mathrm{~g}$ & 9.37125 \\
\hline Triton $\mathrm{X}$ & $3 \mathrm{ml}$ & 1.9275 \\
\hline $\mathrm{N} 719$ dye & $0.2 \mathrm{~g}$ & 100.6 \\
\hline $\mathrm{I}_{2}$ Iodin & $0.24 \mathrm{~g}$ & 4.584 \\
\hline Acetonitrile & $2 \mathrm{ml}$ & 0.8864 \\
\hline Ethylene glycol & $5 \mathrm{ml}$ & 0.61 \\
\hline KI Potassium iodide & 2.49 & 0.447 \\
\hline Graphene coated glass & 2 & 0.1 \\
\hline Indium tin oxide FTO & $2 \mathrm{~g}$ & 5.04 \\
\hline
\end{tabular}

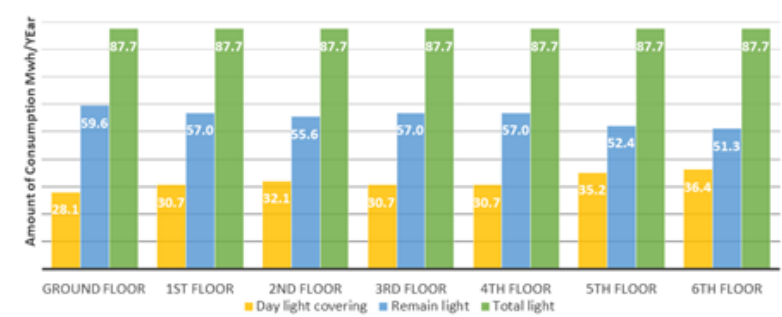

FIG. 9. Office building day-lighting analysis

Numerically, it can be noted that the LCOE for alternative \#2 is nearly double that in alternative \#3 and ten times the LCOE in alternative \#1. However, we should consider that the calculated cost for the MSSC is an in-Lab fabrication cost, where mass production cost should totally differ. Some relevant studies can be found in [38, 39]. Moreover, the integration of new technology for semi-transparent solar cells with bifacial capabilities may be considered as a future booming technology even with relatively higher present cost, as utilizing perovskites and dyes in solar cells for window applications is collecting interests everywhere [40, 41].

\section{Conclusion}

43\% semi-transparent solar cells are introduced in the current feasibilities to replace normal glass in an office building in Egypt. The energy budget for the system under-test has been evaluated using two various alternatives by utilizing the roof area and the glass sides for energy harvesting, while considering the running scenario with grid as the reference alternative. Lighting loads and fire alarms were considered as the targeted loads with optimizing the first through enabling daylight simulations across the year. 100\% targeted load coverage has been achieved in both alternatives \#1 and \#2, while alternative \#2 promotes eight times excess energy to the grid rather than alternative \#1. From an economic perspective, alternative \#1 recorded the lowest LCOE taking into consideration that the cost investigated in alternative \#2 is contributed to the in-Lab fabrication cost which should show rapid minimization whenever it becomes a mass production cost.

\section{Acknowledgment}

The authors would like to acknowledge the support and contribution of the STDF in this work. As part of the STDF Project entitled, "Mesostructured Based Solar Cells for Smart Building Applications", Project ID\#33502. Additionally, the authors would like to thank the Centre for Emerging Learning Technology (CELT), directed by Prof. Hani Ghali, and Nanotechnology research centre (NTRC), directed by Dr. Amal Kassary, in The British University in Egypt for providing all the fabrication facilities needed. Finally, the authors would like to thank Dr. Frank Marllow and his team in MaxPlanck-Institut für Kohlenforschung as the work presented here is considered as an extension for the cooperation and shared publications $[28,30]$.

\section{References:}

[1] Naz S, Sultan R, Zaman K, Aldakhil A M, Nassani A A and Abro M M Q 2019 Moderating and mediating role of renewable energy consumption, FDI inflows, and economic growth on carbon dioxide emissions: evidence from robust least square estimator Environmental Science and Pollution Research 26 2806-19

[2] Samy M, Barakat S and Ramadan H 2019 Techno-economic analysis for rustic electrification in Egypt using multi-source renewable energy based on PV/wind/FC International Journal of Hydrogen Energy

[3] Aliyu A K, Modu B and Tan C W 2018 A review of renewable energy development in Africa: A focus in South Africa, Egypt and Nigeria Renewable and Sustainable Energy Reviews 81 2502-18

[4] Hanna G 2015 Energy analysis for new office buildings in Egypt International Journal of Science and Research 4 554-60

[5] Koch J, Gouda S, Seyppel M, Wiesegart K and Visser F 2015 Energy Efficient 
Lighting: Guidelines and Recommendations for the MENA Region Cairo: MED-ENEC Project

[6] Elsayed N M, Swief R A, Abdellatif S O and Abdel-Salam T S 2019 Photovoltaic Applications for Lighting Load Energy Saving: Case Studies, Educational Building. In: 2019 International Conference on Innovative Trends in Computer Engineering (ITCE), pp 564-9

[7] Zarie M M, Makeen P, Abdellatif S O, Mahmoud I and Abdel-Salam T 2019 Techno-economic Feasibility of Photovoltaic System for an Educational Building in Egypt:(Case Study). In: 2019 International Conference on Innovative Trends in Computer Engineering (ITCE): IEEE) pp 521-5

[8] Schäfer M, Hammad H, Frezza M, ElBassiouny N and Muster V 2018 Transitions of the energy sector in Egypt, Brazil and Germany-a comparison of the interplay between government, the private sector and civil society

[9] Ito K $2017 \mathrm{CO} 2$ emissions, renewable and non-renewable energy consumption, and economic growth: Evidence from panel data for developing countries International Economics 151 1-6

[10] El-Megharbel N $2015 \quad$ Sustainable development strategy: Egypt's vision 2030 and planning reform Proceedings of Integrated Approaches to Sustainable Development Planning and Implementation 27

[11] Ordenes M, Marinoski D L, Braun P and Rüther R 2007 The impact of buildingintegrated photovoltaics on the energy demand of multi-family dwellings in Brazil Energy and Buildings 39 629-42

[12] Peng C, Huang Y and Wu Z 2011 Buildingintegrated photovoltaics (BIPV) in architectural design in China Energy and Buildings 43 3592-8

[13] van der Poel E, van Sark W, Aartsma Y, Teunissen E, van Straten I and de Vries A 2020 Steps Towards an Optimal BuildingIntegrated Photovoltaics (BIPV) Value Chain in the Netherlands, Sustainability in Energy and Buildings Sustainability in Energy and Buildings 2019409

[14] Røyset A, Kolås T and Jelle B P 2020 Coloured building integrated photovoltaics: Influence on energy efficiency Energy and Buildings 208109623
[15] Salem M and Osman T 2016 A new map for urban development in Egypt, depending on mega projects of renewable energy. In: Sustainable Mega Projects Conference, At British University in Egypt,

[16] Kim S, Lee E, Lee Y, Kim J, Park B, Jang $\mathrm{S}$-Y, Jeong S, Oh J, Lee M S and Kang $\mathrm{H}$ 2020 Interface Engineering for Fabricating Semi-transparent and Flexible Windowfilm-type Organic Solar Cells ACS Applied Materials \& Interfaces

[17] Liu D, Sun Y, Wilson R and Wu Y 2020 Comprehensive evaluation of windowintegrated semi-transparent PV for building daylight performance Renewable Energy 145 1399-411

[18] Peng J, Curcija D C, Thanachareonkit A, Lee E S, Goudey H and Selkowitz S E 2019 Study on the overall energy performance of a novel $\mathrm{c}-\mathrm{Si}$ based semitransparent solar photovoltaic window Applied energy 242 854-72

[19] Dobrzycki A, Kurz D, Mikulski S and Wodnicki G 2020 Analysis of the Impact of Building Integrated Photovoltaics (BIPV) on Reducing the Demand for Electricity and Heat in Buildings Located in Poland Energies 132549

[20] Fina B, Auer H and Friedl W 2019 Profitability of active retrofitting of multiapartment buildings: Buildingattached/integrated photovoltaics with special consideration of different heating systems Energy and Buildings 190 86-102

[21] Sanad M F, Abdellatif S O and Ghali H A 2019 Enhancing the performance of photovoltaic operating under harsh conditions using carbon-nanotube thermoelectric harvesters Journal of Materials Science: Materials in Electronics 30 20029-36

[22] Lau S-K, Zhao Y, Lau S S Y, Yuan C and Shabunko V 2020 An Investigation on Ventilation of Building-Integrated Photovoltaics System Using Numerical Modeling Journal of Solar Energy Engineering 142

[23] Salameh T, Assad M E H, Tawalbeh M, Ghenai C, Merabet A and Öztop H F 2020 Analysis of cooling load on commercial building in UAE climate using building integrated photovoltaic façade system Solar Energy 199 617-29

[24] Spiliotis K, Gonçalves J E, Saelens D, Baert K and Driesen J 2020 Electrical system 
architectures for building-integrated photovoltaics: A comparative analysis using a modelling framework in Modelica Applied Energy 261114247

[25] Ng P K, Mithraratne N and Kua H W 2013 Energy analysis of semi-transparent BIPV in Singapore buildings Energy and buildings 66 274-81

[26] Anctil A, Lee E and Lunt R R 2020 Net energy and cost benefit of transparent organic solar cells in building-integrated applications Applied Energy 261114429

[27] Cattaneo G, Faes A, Li H-Y, Galliano F, Gragert M, Yao Y, Grischke R, Söderström $\mathrm{T}$, Despeisse $\mathrm{M}$ and Ballif C 2015 Lamination process and encapsulation materials for glass-glass PV module design Photovoltaics International 27 1-8

[28] Abdellatif S O, Josten S, Khalil A S G, Erni D and Marlow F 2020 Transparency and Diffused Light Efficiency of Dye-Sensitized Solar Cells: Tuning and a New Figure of Merit IEEE Journal of Photovoltaics 1-9

[29] Pearl Kurian C 2020 Opinion: Daylightartificial light integration: Research needs Lighting Research \& Technology 52 4-

[30] Abdellatif S, Sharifi P, Kirah K, Ghannam R, Khalil A, Erni D and Marlow F 2018 Refractive index and scattering of porous $\mathrm{TiO} 2$ films Microporous and Mesoporous Materials 264 84-91

[31] Abdellatif S O and Alsayed G A 2019 Optimizing 1D Photonic Crystal Structures for Thin Film Solar Cells. In: 2019 IEEE Conference on Power Electronics and Renewable Energy (CPERE): IEEE) pp 333-7

[32] Hashem E M, Hamza M A, El-Shazly A N, Sanad M F, Hassan M M and Abdellatif S O 2020 Investigating the UV absorption capabilities in novel Ag@RGO/ZnO ternary nanocomposite for optoelectronic devices Nanotechnology 32085701

[33] Abdellatif S O, Kirah K, Erni D and Marlow F 2020 Modeling disorder in twodimensional colloidal crystals based on electron microscope measurements Appl. Opt. 59 10432-40

[34] CELT-BUE F 2020 PV-ON

[35] LM I 2013 Approved method: IES spatial Daylight autonomy (sDA) and annual sunlight exposure (ASE)

[36] Konstantzos I and Tzempelikos A 2014 Daylight glare probability measurements and correlation with indoor illuminances in a full-scale office with dynamic shading controls

[37] Lu L, Chen J, Li L and Wang W 2012 Direct synthesis of vertically aligned $\mathrm{ZnO}$ nanowires on FTO substrates using a CVD method and the improvement of photovoltaic performance Nanoscale research letters 7293

[38] Tomas Sysala J P, Petr Neumann, 2016 Using Microcomputers for Lighting Appliances Control Via DALI Bus WSEAS Transactions on Systems and Control 11 409-18

[39] Jiri Vincenec M Z 2016 Photometric and electrical properties of the light sources WSEAS Transactions on Power Systems 11 316-22

[40] Li Zhao W M, Mengxia Tang, Songnan Chen, 2020 An Improved White Patch Method for Image Illumination Estimation International Journal of Circuits, Systems and Signal Processing 14 594-9

[41] Deepak Agrawal R K K, Deepak Verma and Rakeshwri Agrawa 2020 DC-DC converter Topologies for LED Driver Circuit: A Review International Journal of Circuits, Systems and Signal Processing 14 542-7

Author Contribution: The main idea and conceptualization for the current study is contributed to the last author (Sameh O. Abdellatif). Concerning the simulation work and feasibility study implementations, all authors contributed equally to the paper in the following manner: M. O. Ahmed, A. K. Madkor and P. Makeen contributed with the PV sizing simulations, while S. I. Betelmal, M. M. Hassan, and S. O, Abdellatif considered the semi-transparent solar cells prototyping and characterization. Mohamed M. Abdelsamee, Ahmed Ayman, Mohamad H. El-Adly tackle the economic analysis and finally, Ashraf Nessim and Sameh O. Abdullatif contributed with the sunlight simulation and the optical analysis respectively.

This article is published under the terms of the Creative Commons Attribution License 4.0 https://creativecommons.org/licenses/by/4.0/deed.en US

\section{Creative Commons Attribution License 4.0} (Attribution 4.0 International, CC BY 4.0)

This article is published under the terms of the Creative Commons Attribution License 4.0

https://creativecommons.org/licenses/by/4.0/deed.en_US 